\title{
Język, logika i soteriologia
}

\section{Language, Logic and Soteriology}

\author{
Michat Lipnicki \\ INSTYTUT JĘZYKOZNAWSTWA, UNIWERSYTET IM. ADAMA MICKIEWICZA \\ AL. NIEPODLEGŁOŚCI 4, 61-874 POZNAŃ \\ lelipou@amu.edu.pl
}

\begin{abstract}
The aim of the article is to describe the notion of language and some "logical" ideas that were developed by one of the greatest figure of Buddhist philosophy - Nāgārjuna. Moreover, this article will present the importance of the logical analysis of language as a factor contributory to the achievement of the ultimate goal of any Buddhist activity - enlightenment (nirvāna).
\end{abstract}

\section{Wstęp}

Definicje określające logikę jako naukę można odnaleźć w niemal każdym z licznych podręczników akademickich wykładających jej podstawy oraz w monografiach zajmujących się bardziej zawansowanymi kwestiami szczegółowymi. Co więcej, nawet $\mathrm{w}$ beletrystyce napotka się próby literackiego uchwycenia jej istoty. Wszak takie pojęcia, jak logiczny i nielogiczny nie są zarezerwowane wyłącznie dla dyskursu naukowofilozoficznego i często pojawiają się w pozanaukowych kontekstach. Prawdopodobnie najbardziej znanym opisem logiki w literaturze popularnej jest, wielokrotnie już cytowana, „definicja” sformułowana przez Tweedledee - postać pojawiającą się w Alicji po drugiej stronie lustra autorstwa Lewisa Carrolla:

Wręcz przeciwnie - ciągnął Tweedledee - jeżeli tak było, to mogło być, a gdyby tak było, to by było; ale skoro tak nie jest, to nie jest. To jest logiczne.

Oczywiście w rozważaniach naukowych tradycja oraz wymogi metodologiczne nakazują, aby definicje formułować w inny, bardziej przejrzysty sposób. W. O. Quine pisze, że logika jest systematycznym 


\section{Michat Lipnicki: Język, logika i soteriologia}

badaniem prawd logicznych. Natomiast zdanie jest logicznie prawdziwe, jeżeli każde zdanie mające jego strukture gramatyczna jest prawdziwe (Quine, 2002: 5). Warto zauważyć, iż definicja zaproponowana przez Quine'a obejmuje wyłącznie jedną z gałęzi szeroko rozumianej logiki logikę formalną.

W tradycji filozoficznej Zachodu przyjęło się, by w tzw. logica magna, czyli wielkiej logice, wyodrębniać trzy dyscypliny poboczne, tj. (a) semiotykę logiczną, (b) metodologię nauk oraz (c) logikę formalną. W ten sposób różnorodne - ze względu na przedmiot zainteresowania przedsięwzięcia zostały poklasyfikowane na grupy o wyodrębnionym obiekcie badań. Umożliwiło to również zdefiniowanie logiki na podstawie trzech definicji cząstkowych (a), (b) oraz (c).

Semiotyka logiczna zajmuje się opisem języka z dwóch perspektyw: (i) konstrukcji systemów formalnych oraz (ii) posługiwania się nim do celów komunikacji, argumentacji i konstrukcji systemów naukowych. Można zatem powiedzieć, że sporą część rozważań tej dziedziny stanowi tzw. pragmatyka logiczna.

W metodologii nauk przedmiotem badań są czynności badawcze lub ich wytwory, takie jak: twierdzenia, teorie, definicje itp.

Logikę formalną poza przytaczaną już definicją Quina określa się w literaturze jako: naukę o formach poprawnego wnioskowania (Malinowski, 2010: 16 ); dział logiki, w którym bada się schematy rozumowań niezawodnych (Marciszewski, 1970: 132).

W historii logiki zachodniej można wyodrębnić trzy główne determinanty jej rozwoju. Po pierwsze, mówi się o próbach systematyzacji technik skutecznej argumentacji i obalania tez głoszonych przez przeciwników w dyskusjach. Ewolucja sztuki debatowania, czyli dialektyki, bo o niej tutaj mowa, jest zazwyczaj pierwszym wyróżnianym etapem, albowiem sięga on najdalej w „logiczną przeszłość”. Postacią, od której zazwyczaj rozpoczyna się historiografię tego trwającego do dzisiaj procesu jest Zenon z Elei żyjący w ok. V w. p.n.e. (por. Bocheński, 1957: 10; Suchoń, 2001: 11).

Rozwój logiki bywa również rozpatrywany w kategoriach gromadzenia „materiału logicznego”. Zgodnie z tym podejściem logika mogła się rozwijać w usystematyzowanej formie dopiero w momencie, gdy zebrało się wystarczająco dużo tego materiału. Propagatorem tej koncepcji był wybitny polski logik Roman Suszko.

Materiał ten - nazwijmy go materiałem logicznym - jest ludzkim wytworem, zmieniającym się i komplikującym poprzez dzieje. Obejmuje wszelkie konstrukcje pojęciowe, twierdzenia, rozumowania i teorie, a dany jest $\mathrm{w}$ wypowiedziach, rozmowach, dyskusjach i wykładach oraz, w stosunkowo trwałej formie, w pismach i traktatach (Suszko, 1998: 22 - 23). 
Dzieła zbadania i sformułowania praw rządzących tym zbiorem dokonał Arystoteles (IV w. p.n.e.).

Ostatnią determinantę można śmiało nazwać językową, ponieważ stanowi ona, że do uformowania się logiki w takim kształcie, $\mathrm{w}$ jakim jest dzisiaj uprawiana, potrzebna była refleksja nad specyficznymi cechami języka naturalnego. Pierwsze systematyczne rozważania tego typu $\mathrm{w}$ Europie również prowadził Arystoteles, przez co uzasadnione jest określanie go mianem ,ojca logiki formalnej”. Czynników wskazujących na zwrot $\mathrm{w}$ stronę poszukiwania strukturalnych determinant prawdziwości wypowiedzi można doszukiwać się już we wcześniejszych działaniach sofistów, którzy za stosowną opłatą oferowali nauki skutecznych technik argumentacji. Relatywistyczne stanowisko w kwestii prawdy, uznawane przez sofistów, pozwalało im na swobodne i efektywne rozwijanie sztuki dowodzenia i uzasadniania wszelkich możliwych twierdzeń, ponieważ, zgodnie z przyjmowanymi założeniami, wszystkie one mogły być prawdziwe. To z kolei przesuwało ciężar dowodu na samą tylko jego strukturę, treść schodziła na dalszy plan. Nie było ważne to, czego się dowodzi, tylko - w jaki sposób.

Oczywiście nie jest tak, że przedstawione powyżej trzy poglądy są nie do pogodzenia. Przeciwnie, wydają się one dopełniać i wspólnie stanowią wypadkową znanego nam, współczesnego, charakteru logiki.

To, co jest niezwykle istotne $\mathrm{z}$ perspektywy naszych dalszych rozważań, to przewijające się przez cały okres rozwoju powiązania refleksji logicznej z językową. Oczywiście nie jest to żadne odkrycie. Wystarczy spojrzeć na liczbę tytułów poważnych dzieł zawierających owe dwa terminy i omawiających ich wzajemne stosunki. Zestawienie ze sobą logiki i języka nie powinno dziwić nikogo, kto posiada choćby najbardziej podstawową wiedzę na temat jednego lub drugiego.

Inaczej rzecz się ma z soteriologią. Dodanie jej, tak jak to ma miejsce w tytule niniejszego artykułu, do pary język i logika może budzić uzasadnione wątpliwości, czy aby nie mamy tu do czynienia z próbą sprowadzenia nas na manowce pseudonaukowych (bądź pseudofilozoficznych) rozważań ezoterycznych. W przypadku refleksji Zachodu takie wątpliwości i podejrzenia wydają się całkiem uzasadnione. Soteriologia jest działem teologii chrześcijańskiej i zajmuje się zbawieniem, które oznacza boski akt mający na celu uwolnienie ludzi z pewnych niekorzystnych dla nich stanów. W takim rozumieniu soteriologii jej związki z logiką mogą objawiać się jedynie na poziomie konstruowania teorii, czyli metodologicznym. Wszak nikt nie może zabronić teologom prób budowania logicznie spójnej teorii zbawienia. Nie o takie związki nam chodzi. Naszym celem jest omówienie logicznej refleksji nad pewnymi właściwościami języka i wskazanie na doniosłość jej roli na drodze prowadzącej jednostkę do wyzwolenia. Jednak aby to uczynić, musimy porzucić nasze rodzime tradycje filozoficzno-naukowo-teologiczne i przenieść się na grunt indyjski, gdzie przyjrzymy się pracy filozoficznej wielkiego buddyjskiego myśliciela - Nagardżuny (Nāgārjuna), w której, jak będziemy starali się pokazać w dalszej części pracy, logika spełnia 
ważną funkcję soteriologiczną. Warto zatrzymać się na chwilę $\mathrm{w}$ tym miejscu, aby odnotować pewne różnice między chrześcijańskim pojęciem zbawienia a buddyjskim wyzwoleniem.

Przede wszystkim w buddyzmie nie pojawia się żadna, ukrywająca się pod postacią absolutu, „ostateczna instancja”, do której należałaby decyzja dotycząca losów jednostki po śmierci - o jej zbawieniu bądź potępieniu. Ludzie sami, żyjąc w określony sposób, kształtują swoje dalsze losy. Jeśli działania nie są dyktowane egoistycznymi pobudkami i mają na celu dobro wszystkich czujących istot, wówczas tworzy się pozytywna karma (karma), owocująca odrodzeniem się $\mathrm{w}$ kolejnych wcieleniach $\mathrm{w}$ korzystnych warunkach ${ }^{1}$. Natomiast jeśli działamy w sposób egoistyczny i przynoszący krzywdę innym istotom, wytwarza się karma negatywna skutkująca odrodzeniem się w niższych sferach egzystencji (np. w świecie zwierząt). Jednakże samo odradzenie się nie jest jeszcze równoznaczne $\mathrm{z}$ wyzwoleniem (mokșa), a wręcz jest jego przeciwieństwem. To, co się zyskuje, to sprzyjające warunki do pracy nad nim. Właściwe wyzwolenie polega na uwolnieniu się z kręgu powtarzających się narodzin i śmierci (samsāra). Zbieranie pozytywnej karmy nie jest celem samym w sobie, tylko drogą prowadzącą do jej ostatecznego wygaśnięcia, kiedy czyny przestają przynosić karmiczny skutek. Stan taki nazywa się nirwaną (nirvāna). Założenie jest takie, że dopóki czujemy przywiązanie do jakichkolwiek aspektów materialnego świata, dopóty odczuwamy cierpienie (duhkha). Wynika to z niewiedzy (avidya), na podstawie której tworzone są błędne poglądy odnośnie do natury zjawiskowego świata postrzeganie jego obiektów jako trwałych i niezmiennych. Z kolei usunięcie niewiedzy, w czym ważną rolę odgrywa logika, prowadzi do poznania sposobu, w jaki obiekty świata zewnętrznego $\mathrm{w}$ stosunku do podmiotu poznającego istnieją naprawdę, co ostatecznie ma prowadzić do wygaśnięcia pożądania i wyzwolenia ${ }^{2}$. Jak widać $\mathrm{w}$ buddyzmie nad wyzwoleniem jednostki nie czuwa żadna opatrzność. Jest ono wyłącznie efektem długiej i żmudnej pracy człowieka nad samym sobą. Oczywiście również sama natura wyzwolenia $\mathrm{w}$ buddyzmie $\mathrm{i}$ zbawienia $\mathrm{w}$ chrześcijaństwie zasadniczo się różnią. Kwestia ta jednak wykracza już daleko poza obszar prowadzonych rozważań, dlatego zmuszeni jesteśmy pozostawić ją bez rozwinięcia.

\section{Nagardżuna i filozofia szkoły madhjamaka (madhyamaka)}

\subsection{Postać Nagardżuny}

Postać wielkiego filozofa buddyjskiego o imieniu Nagardżuna jest bardzo tajemnicza. Niewiele wiemy na temat dokładnego okresu jego życia ani też

\footnotetext{
${ }^{1} \mathrm{~W}$ wielkim skrócie pod pojęciem karmy kryją się wszelkie zamierzone i podejmowane z własnej woli uczynki ciała (działanie), umysłu (myślenie) oraz mowy.

${ }^{2}$ Oczywiście jest to model niezwykle uproszczony i szkicuje on tylko bardzo ogólny zarys problemu.
} 
o jego przebiegu. Mimo tego powszechnie przyjmuje się, że Nagardżuna działal około II w. n.e. (por. Gethin, 2010: 223; Williams, 2001: 76). Chociaż nie są znane niemal żadne fakty mówiące o jego życiu, to istnieje wiele legend na ten temat. Jedna z nich wiąże go z objawieniem światu sutr pradżniaparamity (prajñāpāramita), bardzo ważnych tekstów kanonicznych buddyzmu nurtu mahajana. Otóż Nagardżuna miał być bardzo chorowitym dzieckiem i przez to został oddany do klasztoru buddyjskiego przez matkę, aby tam się nim odpowiednio zaopiekowano. Wkrótce okazało się, że młody adept w bardzo szybkim tempie osiągnął niezwykła biegłość $\mathrm{w}$ alchemii, medycynie i zrozumieniu doktryny buddyjskiej. Wprawił tym w zdumienie mitycznych nagów - ludzi-węży, którzy zaprosili go do swojego królestwa. Po przybyciu Nagardżuna odnalazł tam pozostawione przez Buddę sutry, czekające aż ludzkość dojrzeje do przyjęcia zawartych w nich nauk. Powracając do świata ludzi, zabrał je ze sobą, aby ogłosić je z pożytkiem dla wszystkich czujących istot.

\subsection{Filozofia madhjamaki}

Zanim przejdziemy do omawiania poglądów Nagardżuny na język i jego metody logicznej, musimy w skrócie przedstawić podstawowe założenia filozoficzne reprezentowanej przez tego myśliciela szkoły. W przeciwnym razie spora część dalszych rozważań może okazać się niezrozumiała.

Mówiąc o kluczowych zagadnieniach myśli Nagardżuny należy wspomnieć o trzech koncepcjach: (a) dwóch prawdach - konwencjonalnej (samvrti-sat) oraz ostatecznej (paramārtha-sat); (b) współzależnym powstawaniu (pratītyasamutpāda); (3) pustce (śūnya)3.

Rozróżnieniu dwóch prawd towarzyszy pojęcie dwóch oglądów rzeczywistości. Ogląd konwencjonalny to poznanie, w którym obiekty i zjawiska uważa się za trwałe i posiadające istotę, samobyt (svabhāva). Na tym poziomie obiekty poznania są charakteryzowane przez różne cechy i określony jest stosunek podmiotów poznających do nich: pozytywny, neutralny bądź negatywny. Zasadniczo uważa się, że jest to ogląd błędny, przesłaniający prawdę ostateczną o świecie4. Prawda ostateczna mówi, że przedmioty błędnie uznawane za trwałe, istniejące niezależnie i posiadające istotę, $\mathrm{w}$ rzeczywistości są współzależne od innych obiektów i nie mają żadnych własności będących „dodatkami” przypisanymi im w konceptach podmiotów poznających. Właśnie z tego wynika ich pustka; nie istnieją one w sensie absolutnym (ani też nie nie istnieją!).

Współzależne powstawanie mówi, że żadne zjawisko, czy byt, nie istnieje samo $\mathrm{z}$ siebie, tylko zależy od niezliczonych warunków wpływających na jego powstanie. W ten sposób rzeczy są puste, ponieważ nie posiadają samoistności, żadnego bytu samego w sobie. Taka jest ostateczna natura wszelkich zjawisk. Sünya nie jest więc prostym

\footnotetext{
${ }^{3}$ Termin śūnya pierwotnie był używany w matematyce indyjskiej na oznaczenie zera i jego użycie daje się odnotować już przed Nagardżuną (por. Matilal, 1971: 152).

${ }^{4}$ Czasami w literaturze przedmiotu można spotkać thumaczenie paramārtha-sat jako „prawda absolutna".
} 
nieistnieniem, czy pustą przestrzenią. Wszystko, co uważamy za istniejące, jest tylko ciągle zmieniającym się potokiem zdarzeń, którego kształt ustalany jest przez ciąg wzajemnych uwarunkowań jego elementów. W ten sposób to, co jawi się nam, podmiotom poznającym, jako istniejące niezmiennie, tak naprawdę powstaje tylko $w$ zależności od innych obiektów. Oto jak w wielkim skrócie przedstawia się prawo współzależnego powstawania. Żyjemy w sprytnie ukutej iluzji trwałości i niezmienności świata zewnętrznego w stosunku do nas, podczas gdy rzeczywistość empiryczna jest w gruncie rzeczy pozbawiona istoty. $Z$ kolei na poziomie prawdy ostatecznej zanikają wszelkie manifestacje myśli, koncepty i wyrażenia języka. Stąd wszelki pogląd, jaki żywimy na poziomie empirycznym, jest ze swojej natury konwencjonalny, językowo wyrażalny, a w efekcie błędny i pozbawiony istoty z perspektywy prawdy ostatecznej. Pustka i zależne powstawanie są w gruncie rzeczy dwoma aspektami tego samego zjawiska: to co powstaje $w$ zależności jest puste (...) wszystko, co istnieje, istnieje zależnie (LS 22).

W związku z tym, że wszelkie obiekty, zjawiska i koncepcje istnieją tylko zależnie (względnie), nie można o nich jednoznacznie orzekać, że istnieją lub nie istnieją, że posiadają jakąś cechę lub jej nie posiadają. Madhjamaka unika wszelkich stanowisk jednoznacznie opowiadających się za danym stanem rzeczy i stara się pokazać, że właściwe podejście leży pomiędzy dwoma ekstremami - jest i nie jest. Dlatego nazywa się ją filozofią środkowej ścieżki. Nagardżuna twierdzil, nie bez racji, że podstawy takiego podejścia odnajduje się już w słowach Buddy:

„Istnieje” jest dogmatem eternalistów. „Nie istnieje” jest dogmatem nihilistów. Jednak Ty [Budda] pokazałeś prawo powstawania w zależności, wolne od tych dwóch skrajności (AS 22).

Cytat ten nawiązuje do znanego fragmentu pochodzącego ze zbioru sutr Kanonu Palijskiego Samyutta Nikaya5. W tym fragmencie Budda rozmawia z wędrownym ascetą Waczczhogottą (Vacchogotta).

Wtedy wędrowny asceta Waczczhagotta zwrócił się do Wzniosłego w te słowa: «Jak się przedstawia ta sprawa czcigodny Gotamo, czy istnieje jaźń?» Jednak po tym pytaniu wzniosły zachował milczenie. «O czcigodny Gotamo, czy zatem jaźń nie istnieje?» A Wzniosły w dalszym ciągu zachował milczenie. Wtedy wędrowny

\footnotetext{
${ }^{5}$ Mówiąc o Buddyjskim Kanonie Palijskim, ma się na myśli zbiór świętych tekstów buddyjskiej szkoły therawadinów, które spisano w języku palijskim. Właściwy kanon buddyjski zawiera trzy typy tekstów zwane koszami, a ich zbiór nosi nazwę Tipitaka. Pierwszy zbiór to Kosz dyscypliny (Vinaya Pitaka) dotyczący zasad postępowania wspólnoty religijnej, następnie wymienia się Kosz kazań (Sutta Pitaka) oraz Kosz wyższej doktryny (Abhidhamma Pitaka), w którym rozważane są szczegółowo różne zagadnienia doktrynalne (M. Mejor, 2001: 133 - 136).
} 
asceta Waczczhagotta powstał ze swego siedzenia i odszedł. Lecz czcigodny Ananda rzekł do Wzniosłego: «Dlaczego, o Panie, Wzniosły nie dał odpowiedzi na pytanie wędrownego ascety Waczczhagotty? » «O Anando, gdybym odpowiedział na pytanie wędrownego ascety Waczczhogatty „Czy jaźń istnieje?” słowami: Jaźń istnieje, to potwierdziłbym doktrynę samanów i braminów, którzy wierzą w nieprzemijalność. Gdybym, o Anando, odpowiedział na pytanie wędrownego ascety Waczczhogatty „Czy jaźń nie istnieje?” słowami: Jaźni nie ma, to potwierdziłbym doktrynę samanów i braminów, którzy wierzą w unicestwienie. " (Samyutta Nikaya IV 43.1.10. tłum. na podstawie: Radhakrishnan, 1951: 370)

\section{Język i logika}

\subsection{Język}

Doktryna współzależnego powstawania $\mathrm{w}$ takiej formie, jak została przedstawiona powyżej, opisuje pustkę $\mathrm{z}$ perspektywy ontologicznej. Natomiast z perspektywy epistemologicznej mówi się o zależnym desygnowaniu. Obydwa pojęcia reprezentują dwa aspekty tego samego zjawiska (Matilal, 1971: 150). W Mūlamadhyamakakārikā czytamy:

\footnotetext{
Wszystko, co powstaje w zależności od czegoś innego, Jest puste.

To, będąc zależnym desygnowaniem, Konstytuuje Środkową Ścieżkę (MMK XXIV 18).
}

Tak, jak każda rzecz istnieje tylko w zależności od innych rzeczy, tak i wszelkie nazwy oznaczają swoje obiekty w sposób zależny od innych. $\mathrm{Na}$ przykład mówiąc o istocie ludzkiej tak naprawdę nie wskazujemy na coś, co istnieje samo w sobie, tylko na kombinację pięciu zespołów (skandha), czterech psychicznych (uczuć, przedstawień, dyspozycji i świadomości) i jednego fizycznego (materii). Nazwanie suponuje, jakoby istniał obiekt posiadający określone, trwałe atrybuty, o którym można by zgodnie $\mathrm{z}$ prawdą tę nazwę orzec. Dlatego, jak zauważa Nagardżuna, język nas zwodzi - tworzy pozory trwałości tam, gdzie jest permanentna zmiana; sugeruje istnienie istoty każdego swego desygnatu, podczas gdy $\mathrm{w}$ rzeczywistości wszystko jest puste. Co więcej, wprowadzając pojęcie zależnego desygnowania wskazuje się, że nie jest możliwe językowe uchwycenie świata wymykającego się poznaniu konceptualnemu. Nazywając dane wrażenie reifikujemy je $\mathrm{w}$ pojęciu i zatrzymujemy $\mathrm{w}$ formie konceptu zniekształcającego nasz pogląd na rzeczywistość. Wszelka konceptualizacja jest błędna z samej swojej natury, a każdy koncept jest równie pusty jak jego, rzekomo istniejące, odniesienie. Innymi słowy, nazwanie obiektu spaja wszystkie warunki wyznaczające jego manifestację 


\section{Michat Lipnicki: Język, logika i soteriologia}

i utrwala je w jednym pojęciu ujmującym dany obiekt jako istniejący indywidualnie (niezależnie od składających się nań warunków) i trwale (posiadający istotę). Wydaje się, że w takiej sytuacji, aby nazwę jakiegoś obiektu można było uznać za właściwą, powinna ona wskazywać na wszelkie warunki, od których zależy jej desygnat. Oczywiste jest, że język nie funkcjonuje $\mathrm{w}$ ten sposób i funkcjonować nie może. W takiej sytuacji każda nazwa mogłaby być użyta tylko raz, ponieważ żaden obiekt nie istnieje przez dwie następujące po sobie chwile. Nazwanie dwóch różnych manifestacji tą samą nazwą sugeruje natomiast, iż istnieje jakaś esencja wspólna dla wszystkich manifestacji danego obiektu, co jest nie do pogodzenia z filozofią buddyjską w ogóle. Poza tym koncepty i nazwy reprezentują swoje przedmioty abstrahując od ich rzeczywistych uwarunkowań, dlatego sugerują ich niezależne istnienie. Można sobie wyobrazić, że nazwa oddająca całą złożoność zależności wpływających na desygnat byłaby raczej zbyt skomplikowana, by mogła spełniać swoją funkcję komunikacyjną.

W taki sposób koncepty, a z nimi język, przesłaniają rzeczywistość w jej ostatecznym wymiarze. W związku $\mathrm{z}$ tym, że spora część „spetryfikowanych” koncepcji dotyczy danych zmysłowych, bądź powstaje na ich podstawie, poziom konwencjonalny nazywa się również empirycznym. Niezwykle istotne jest to, że na poziomie prawdy konwencjonalnej możemy rozważać w sposób konceptualny jej błędność i nauczać o prawdzie ostatecznej, gdzie nie istnieją już żadne rozróżnienia umożliwiające formowanie się koncepcji. Jak opisuje rzecz Matilal (1971: 153): aplikacja słów polega na przypisaniu danemu zjawisku pewnych cech (nimitta). Scharakteryzowany wstępnie obiekt staje się więc przedmiotem świadomości (citta-gocara) przez nadanie mu pewnej formy, która z kolei jest warunkiem nadania odpowiedniej nazwy.

Konstatacja, iż konceptualizacja oraz związana z nią aktywność językowa są przeszkodami na drodze do doświadczenia prawdy ostatecznej i wyzwolenia, prowadzi Nagardżunę do ważnej tezy głoszącej, iż nic, co jest wyrażane w języku, nie jest rzeczywiste (MMK XXIII 7). Z kolei w innym dziele: Acintyastava Nagardżuna stwierdza, że istnienie świata jest prostym następstwem nazywania odbieranych bodźców i ich reifikacji w odpowiednich konceptach. Świat jest tylko konwencją wynikającą z działalności językowej. Podobno sam Budda ogłosil, że wszystko jest tylko nazwą, a nic, co może być wyrażone, nie istnieje poza samym wyrażeniem (AS 36). W tekście Bodhicittavivarana jest powiedziane, iż żadne obiekty zewnętrzne nie istnieja poza świadomościa (BV 22), co można błędnie obrać za stwierdzenie idealistyczne, a wręcz solipsystyczne. Należy pamiętać, że świadomość, tak jak wszystko inne, również jest konceptem, a więc i ona musi zostać odrzucona. Idealizm jest zatem nie do utrzymania. Filozofię Nagardżuny można tu przyrównać do swoistej ścieżki dydaktycznej, w której stopniowo, na kolejnych stadiach poznawczych odrzuca się błędne poglądy. Zaczynamy od realizmu odrzucanego przez stwierdzenie, że wszelkie rzeczy są tylko wytworami świadomości, czyli wstępnie zakładamy idealizm. Idealizm odrzucamy, poprzez stwierdzenie, 
że wszystko jest tylko nazwą i bytu jako takiego nie posiada. Nawet świadomość jest tylko pustym konceptem, któremu nie odpowiada żaden rzeczywisty i trwały obiekt (umyst $i$ świadomość to tylko nazwy (BV 40 41). Ostatni krok to odrzucenie języka i samej koncepcji pustki. Nie posiada on nazwy, ponieważ istnieje poza językiem i jest równoważny ze stanem oświecenia.

\subsection{Logika}

Rola logiki w filozofii Nagardżuny jest bardzo istotna z punktu widzenia celu, w jakim powinno się podejmować wszelką refleksję, tj. wyzwolenia z kołowrotu wcieleń, osiągnięcia nirwany i poznania prawdy ostatecznej. To właśnie przy pomocy logiki obnaża się iluzoryczność językowo skonstruowanego świata oraz usuwa przyczyny błędnego poglądu co do jego natury. Czyni się to przez analizę istniejących w języku pojęć. Metodę stosowaną przez Nagardżunę nazywa się prāsañga „wyciąganie niepożądanej konsekwencji”. Z samej swojej natury jest to pewna forma rozumowania nazywanego współcześnie „sprowadzanie do absurdu”, opierającego się na prawie logicznym reductio ad absurdum. Autor Mūlamadhyamakakārikā pokazuje, że przyjęcie określonych twierdzeń mających za podstawę pojęcia (czyli de facto wszelkich twierdzeń) prowadzi w ostateczności do sprzeczności, co ma pokazywać błąd tkwiący $\mathrm{w}$ przyjmowanym założeniu. Zakładamy, że jakiś obiekt $x$ istnieje niezależnie i pokazujemy, że wówczas nie jest $\mathrm{w}$ ogóle możliwe jego jednoznaczne określenie lub samo założenie prowadzi do różnych niepożądanych, często absurdalnych, konsekwencji. W dziele MMK stosując tę metodę poddaje analizie podstawowe pojęcia, na jakich opiera się nasze poznanie rzeczywistości.

Sama struktura metody prāsañga opiera się na interpretacji koncepcji czterostopniowej charakterystyki obiektów - catuskoți. Koncepcja ta pojawia się już we wczesnych tekstach Kanonu Palijskiego i bywa nazywana w literaturze dwuwartościowa logikq czterech alternatyw (Jayatilleke, 1963: 339) lub tetralematem. Mówi ona o czterech stanowiskach (alternatywach), które można zająć w określonej kwestii. Ich forma przedstawia możliwe związki zachodzące między podmiotem a danym orzecznikiem. Są to stwierdzenia następującej postaci:
(1) $S$ jest $P$,
(2) $S$ jest nie- $P$,
(3) $S$ jest $P$ i nie- $P$,
(4) $S$ nie jest $P$ ani nie- $P$.

Od razu rzuca się w oczy pogwałcenie prawa sprzeczności pojawiające się w punkcie (3). W rzeczywistości, jak wskazuje Jayatilleke (1963: 343), w schematach tego typu nie wykorzystuje się własności sprzecznych tylko przeciwne. Dlatego też możliwa jest taka sytuacja, że przedmiot posiada cechę $P$ oraz nie- $P$, ponieważ ta druga oznacza dowolną cechę nie będącą $P$. Tak właśnie rzecz się ma w następujących, klasycznych przykładach:
1a) osoba krzywdząca samą siebie,
1b) dusza jest bardzo szczęśliwa,
2b) dusza jest bardzo smutna, 
2a) osoba krzywdząca innych, 3a) osoba krzywdząca samą siebie i innych,

4a) osoba nie krzywdząca ani samej siebie, ani innych. 3b) dusza odczuwa mieszane uczucia szczęścia i smutku, 4b) dusza nie odczuwa uczuć szczęścia ani smutku.

Jednak w sutrach można napotkać i inne przykłady, w których sprzeczność cech z (1) i (2) wydaje się być bardziej prawdopodobna niż ich przeciwieństwo:

1c) świat jest skończony,

2c) świat jest nieskończony,

3c) Świat jest skończony i nieskończony,

4c) świat nie jest ani skończony ani nieskończony.

W tym przypadku również można uniknąć sprzeczności, gdyż, jak wskazuje analiza lingwistyczna tego przykładu (por. Jayatilleke, 1963: 340-341), w 1c) i 2c) jest mowa o byciu skończonym i nieskończonym we wszystkich wymiarach, natomiast w 3c) i 4c) chodzi o bycie skończonym w niektórych wymiarach i nieskończonym w innych. Nie będziemy tutaj referować całej problematyki, jaka się wiąże z zagadnieniem logiki czterech alternatyw, odsyłając jednak wszystkich zainteresowanych do ciekawej polemiki, jaka toczyła się na łamach periodyku Philosophy East \& West ${ }^{6}$. Ważną cechą catușkoti jest zasada, zgodnie z którą jedna i tylko jedna z opcji musiała być prawdziwa (Robinson, 1957: 301-302)7. Schemat catusskoti doczekał się w literaturze licznych interpretacji, przy pomocy których próbowano uchwycić jego istotę.

Ciekawy, chociaż jak się wydaje z dzisiejszej perspektywy nietrafny, jest pomysł K. N. Jayatilleke przedstawiony w artykule The Logic of Four Alternatives. Autor odwołuje się do języka rachunku zdań, który, aby lepiej oddać specyfikę problemu, poddany zostaje odpowiednim modyfikacjom. Pierwsze zdanie alternatywy mówiące, że „S jest całkowicie $P$ ” oznacza przez $p$; jego negacje,$S$ jest całkowicie nie- $P$ ” przez,$\rightarrow p$ ”. Nowy symbol wprowadzony przez Jayatilleke to funktor zdaniotwórczy od argumentów zdaniowych,$\Delta "$. Postawiony przed zdaniem $p(\Delta p)$ modyfikuje jego pierwotne znaczenie, tak że wyraża ono sąd postaci „S jest częściowo $P$ ”. Odpowiednio negacja $\Delta \rightarrow p$ mówi, że „S jest częściowo nie-P”. Cztery alternatywy przyjmują następującą postać:

5c) p,

\footnotetext{
${ }^{6}$ Zwłaszcza: Robinson, R. H. 1957. Some Logical Aspects of Nāgārjuna System. w: Philosophy East and West vol. 6. pp. 291-308; Jayatilleke, K. N. 1967. The Logic of Four Alternaives. w: Philosophy East and West vol. 17. 1957. pp. 69-83; Wayman, A. 1977. Who Understands the Four Alternatives of the Buddhist Texts? w: Philosophy East and West vol. 27. pp. 3-21; Gunaratne, R. D. 1980. The Logical Form of Catușkoți: A New Solutnion. w: Philosophy East and West vol. 30. pp. 211-239; Bharadwaja, V. K. 1984. Rationality, Argumentation and Embarrassment: A Study of Four Logical Alternatives (catușkoți) in Buddhist Logic. w: Philosophy East and West vol. 34. pp 303-319.

${ }^{7}$ Pomijamy przypadek, w którym żadne ze stwierdzeń nie może zostać uznane. Jest to szczególna sytuacja. I wiąże się z odpowiadaniem na źle postawione pytania, np. „czy tathăgata istnieje po śmierci?" lub wszelkie pytania zawierające nazwę pustą w funkcji podmiotu.
} 
6c) $\rightarrow \mathrm{p}$,

7c) $\Delta \mathrm{p} \wedge \Delta \rightarrow \mathrm{p}$,

8c) $\quad \neg[\mathrm{p} \vee \rightarrow \mathrm{p} \vee(\Delta \mathrm{p} \wedge \Delta \rightarrow \mathrm{p})]$.

Interpretacja ta poddana została krytyce tak $\mathrm{z}$ perspektywy jej adekwatności, jak i aplikowanej aparatury logicznej. W kwestii samej interpretacji najwięcej kontrowersji budzi krok 4d), w którym wykorzystana została alternatywa rozłączna. Przyjmując proponowaną interpretację spójnika $\Delta$, należałoby ją raczej wyrazić stosując formulę postaci (Gunaratne, 1980: 220):

$\left.4 \mathrm{~d}^{\prime}\right) \neg \Delta p \wedge \neg \Delta \rightarrow p$.

Inny problem, również sygnalizowany w artykule R. D. Gunaratne (1980: 217), dotyczy samego spójnika $\Delta$. Zarzut jest taki, iż dysponując nim w ogóle nie potrzebne jest wprowadzanie $\Delta \rightarrow p$, ponieważ samo wyrażenie postaci $\Delta p$ głoszące:,$S$ jest częśsiowo $P$ ” implikuje zdanie postaci $\Delta \rightarrow p:, S$ jest częściowo nie- $P$ ”. Innymi słowy, jeżeli prawdziwe jest zdanie: „S jest częściowo $P$ ", to fałszywe jest zdanie: „S jest całkowicie $P$ ”, a wówczas prawdziwe musi być również zdanie: „S jest częściowo nie- $P$ ”.

Ponadto wydaje się, że spójnik jednoargumentowy $\Delta$ „przemyca” do systemu buddyjskiego trzecią wartość logiczną, chociaż Jayatilleke stosując go, jednocześnie konsekwentnie obstaje przy dwuargumentowości. Przyjrzyjmy się bliżej temu problemowi. W logice klasycznej dysponujemy czterema jednoargumentowymi spójnikami prawdziwościowymi:

(i) negacji - zmieniającym zdanie fałszywe $\mathrm{w}$ prawdziwe, a prawdziwe w fatszywe: jeżeli $p=0$, to $\neg p=1$, a jeśli $p=1$, to $\neg p=0$;

(ii) asercji - zmieniającym zdanie fałszywe $\mathrm{w}$ fałszywe a prawdziwe $\mathrm{w}$ prawdziwe: jeżeli $p=0$, to $A p=0$, a jeśli $p=1$, to $A p=1$;

(iii) verum - zmieniającym zdania prawdziwe $\mathrm{i}$ fałszywe $\mathrm{w}$ zdania prawdziwe: jeżeli $p=0$, to $V p=1$, a jeśli $p=1$, to $V p=1$;

(iv) falsum - zmieniającym zdania fałszywe i prawdziwe $\mathrm{w}$ zdania fałszywe: jeżeli $p=0$, to $F p=0$, a jeśli $p=1$, to $F p=0$.

Gdy spróbujmy w taki sam sposób opisać spójnik $\Delta$, to jedyna możliwość przed jaką stoimy, przyjmując interpretację sugerowaną jego użyciem, jest następująca: jeżeli $p=0$, to $\Delta p=$ częściowo 1 a częściowo o, natomiast jeśli $p=1$, to $\Delta p=$ częściowo 1 a częściowo o. Rzeczywiście, załóżmy, że przy pomocy alternatyw catuskkoț rozważamy następujący problem: „czy zdanie $s$ jest prawdziwe?”. Musimy zatem rozpatrzyć cztery możliwości:

1e) Zdanie $s$ jest całkowicie prawdziwe.

2e) Zdanie $s$ jest całkowicie fałszywe.

3e) Zdanie $s$ jest częściowo prawdziwe i częściowo fałszywe.

4e) Zdanie $s$ nie jest ani częściowo prawdziwe, ani częściowo fałszywe. Zgodnie z wcześniejszymi uwagami 3e) można zredukować do równoważnego „Zdanie $s$ jest częściowo prawdziwe”. Takie określenie każe nam uznać, że w ten sposób zostaliśmy wyprowadzeni z dwuwartościowej logiki, gdzie zdanie $s$ mogłoby być albo prawdziwe, albo fałszywe. Kwestią innej natury jest pytanie, na ile ta zawoalowana trójwartościowość wynika $\mathrm{z}$ interpretacji, a na ile jest zawarta w samej koncepcji catuskoți. 
Będąc niezadowolonym z propozycji Jayatilleke, Gunaratne (1980: 221-239) proponuje interpretacje przy pomocy rachunku zbiorów. Przy okazji klasyfikuje on różne formy catușkoți w grupy podpadające pod wspólny schemat interpretacyjny. Poniżej prezentujemy interpretację tylko jednego typu przykładu (1c) - (4c):
1f) $x \in A \cap B^{\prime}$
2f) $x \in A^{\prime} \cap B$,
3f) $x \in A \cap B$,
4f) $x \in A^{\prime} \cap B^{\prime}$

Gdzie $x$ jest obiektem jednostkowym, $A$ oznacza zbiór rzeczy skończonych, $B$ zbiór rzeczy nieskończonych, a użyte spójniki wyrażają: „ก” iloczyn zbiorów, "” dopełnienie odpowiedniego zbioru. Problematyczne $\mathrm{w}$ tej interpretacji wydaje się to, że autor odwołuje się do pojęcia dopełnienia zbioru bez określenia uniwersum, w którym operuje.

Nagardżuna na użytek swojej metody zreinterpretował metodę catuskotii. O ile w klasycznych dziełach jedna i tylko jedna alternatywa musiała być prawdziwa, o tyle $\mathrm{w}$ jego systemie ostatecznym celem analizy jest odrzucenie wszystkich czterech możliwości. Nie chodzi tutaj o rozszerzenie zakresu źle postawionych pytań - uniemożliwiających podanie odpowiedzi, lecz o konsekwentne sprowadzanie do absurdu wszelkich pozytywnych twierdzeń i teorii jednoznacznie orzekających jakieś fakty na temat rzeczywistości empirycznej.

Zgodnie $\mathrm{z}$ podstawowymi założeniami catuskoți do danego, rozpatrywanego zagadnienia można podejść z czterech perspektyw, tak jak to przedstawiają przytaczane powyżej alternatywy ze schematów (1) - (4). Nagardżuna, na co wskazuje J. Ganeri (2004 :331), poza analizowaniem zagadnień wpisujących się $\mathrm{w}$ ten schemat, $\mathrm{w}$ dużej mierze rozważa także zależności relacyjne. Wówczas mamy cztery możliwości postaci:

1g) $R$ zachodzi tylko między $x$ i $x$, czyli jest relacją diagonalną;

2g) $R$ zachodzi tylko między $x$ i innymi obiektami różnymi od $x$ - jest relacją przeciwzwrotną;

3g) $R$ zachodzi między $x$ i $x$ oraz między $x$ i innymi obiektami różnymi od $x$

4g) $R$ nie łączy $x$ z żadnym obiektem.

Takie ujęcie logiki catuşkoti, przy jej klasycznej, zgodnej z Kanonem Palijskim interpretacji, zachowuje podstawową własność mówiącą, że jedna i tylko jedna $\mathrm{z}$ czterech alternatyw jest prawdziwa. $\mathrm{W}$ istocie, jeśli założymy, że pierwsza możliwość jest prawdziwa, to zgodnie z definicją relacji diagonalnej mamy:

(d1) $\forall x \in X[R(x, x) \wedge \forall y \in X(y \neq x \rightarrow \neg R(x, y) \wedge \neg R(y, x))]$.

Na mocy (d1) nie jest możliwe aby istniał dowolny element rozważanego zbioru różny od $x$, który byłby z nim w relacji $R$, a zatem nie jest możliwe aby były prawdziwe $2 \mathrm{~g}$ ) oraz $3 \mathrm{~g}$ ). Wykluczona jest też prawdziwość możliwości $4 \mathrm{~g}$ ), ponieważ uznając $1 \mathrm{~g}$ ) stwierdza się, że istnieje obiekt pozostający w relacji $R$ do $x$ - jest to właśnie $x$. 
Zakładając, że druga możliwość jest prawdziwa, czyli $R$ jest relacją przeciwzwrotną, mamy:

$(\mathrm{d} 2) \neg \exists x R(x, x)$ lub $\forall x \forall y(R(x, y) \rightarrow x \neq y)$.

$\mathrm{W}$ takiej sytuacji musimy odrzucić jednoczesną prawdziwość 2g) oraz 3g), ponieważ trzecia alternatywa mówi, że:

$\left(\mathrm{d}_{3}\right) \exists x \exists y(R(x, x) \wedge R(x, y))$.

Zatem nie jest możliwa sytuacja aby (d3) było zdaniem prawdziwym przy jednoczesnej prawdziwości zdania (d2). Ponieważ w (2g) stwierdza się, że $R$ zachodzi tylko między $x$ i różnymi od niego obiektami, to, aby wykluczyć równoczesną prawdziwość $4 \mathrm{~g}$ ), należy założyć, że takie obiekty rzeczywiście istnieją. Taka kwantyfikacja wydaje się być suponowana $\mathrm{w}$ powyższym schemacie, zwłaszcza w drugim sformułowaniu (d2).

W zdaniu $4 \mathrm{~g}$ ) stwierdzamy, że nie istnieje taki obiekt $x$, który relacja $R$ łączy $\mathrm{z}$ dowolnym obiektem uniwersum. Jeśli rzeczywiście tak jest, wówczas możliwości 1g), 2g), 3g) siłą rzeczy są fałszywe, ponieważ każda z nich zakłada, że relacja $R$ łączy $x$ z jakimiś obiektami.

Teraz pokażemy, że przy kanonicznym rozumieniu czterech alternatyw $\mathrm{w}$ ujęciu relacyjnym nie jest możliwe, aby wszystkie były jednocześnie fałszywe. Załóżmy dla dowodu nie wprost, że tak jest, wówczas 1g), 2g), 3g), 4g) są fałszywe. Szczególnie nie jest tak, jak mówi $4 \mathrm{~g}$ ), czyli istnieje przynajmniej jeden taki obiekt, dla którego relacja $R$ zachodzi. Wówczas konieczne jest, aby jedna z pozostałych alternatyw była prawdziwa, co jest sprzeczne z założeniem wyjściowym, które w związku z tym należy odrzucić. A zatem zawsze dokładnie jedna $\mathrm{z}$ opcji musi być prawdziwa.

Tak należałoby zinterpretować relacyjne ujęcie catușkoți, chcąc pozostać wiernym tradycyjnemu jej rozumieniu. Nagardżuna jednak wyraźnie się z nią nie zgadza i twierdzi, że żadna z czterech opcji nie da się utrzymać i musi zostać odrzucona. Precyzuje on, jaką postać mogą przyjąć możliwości do rozpatrzenia w rozważaniach nad danym zagadnieniem, np. relacji bycia przyczyna i następnie wyciąga z każdej możliwości niepożądane konsekwencje, co z kolei ma prowadzić do sukcesywnego odrzucenia każdej z czterech opcji, np. w MMK XVIII.8. czytamy:

Niektórzy twierdzą, że cierpienie powstaje samo z siebie, albo $\mathrm{z}$ czegoś innego lub $\mathrm{z}$ dwóch powyższych jednocześnie, albo że powstaje bez przyczyny.

Ponieważ nie ma innego sposobu spojrzenia na przedmiot rozważań niż cztery przytoczone podejścia, to po ich zanegowaniu okazuje się, że badana relacja jest konceptem pozbawionym istoty - pustym i dlatego nie odpowiada jej żadne obiektywnie istniejące zjawisko. Można powiedzieć, że zdanie wyrażające sąd „ $R(x, y)$ ” w ogóle nie posiada wartości logicznej, co wyklucza je ze zbioru zdań mogących zgodnie z prawdą opisywać rzeczywistość (Ganeri, 2004: 334). W ten sposób musimy odrzucić 


\section{Michat Lipnicki: Język, logika i soteriologia}

wszelkie koncepty tworzące naszą siatkę pojęciową, ponieważ żaden z nich nie jest w stanie wytrzymać tak przeprowadzonej krytyki ${ }^{8}$.

Zobaczmy, jak rzecz się ma w praktyce: w MMK I.1 Nagardżuna rozważa zagadnienie powstawania zjawisk i dochodzi do wniosku, że nic nigdy nie mogło powstać, czyli nic nie istnieje, bo nie jest możliwe, aby „wszystko istniało zawsze”. Rozpatrujemy cztery możliwości. Po pierwsze coś może powstać samo z siebie, po drugie z czegoś innego, po trzecie z obydwu pierwszych razem i po czwarte - bez przyczyny. Następnie Nagardżuna poddaje cztery powyższe sytuacje gruntownej analizie. Nic nie może powstać samo z siebie, ponieważ musiałoby już istnieć wcześniej. Zatem to, z czego powstało, też musiało kiedyś powstać. Prowadzi to do sytuacji, w której cały cykl rozwija się ad infinitum, a to, jak twierdzi filozof, niczego nie wyjaśnia lub postuluje istnienie jakiegoś niemającego początku bytu będącego „sprawcą” pierwszego powstania, co jest w sprzeczności z pierwotnym założeniem. W drugim przypadku, jeżeli coś zawsze powstaje $\mathrm{z}$ czegoś innego, co jest podstawową treścią formuły powstawania $\mathrm{w}$ zależności, to nie jest to nic innego jak wewnętrznie sprzeczne myślenie w kategoriach skutku i przyczyny. Dzieje się tak, ponieważ według filozofa przyczyna zakłada istnienie skutku, bez którego nie jest ona przyczyną. W takim wypadku skutek musi istnieć, zanim zaszła jego przyczyna, czyli skoro już istnieje, to nie wymaga przyczyny, co z kolei prowadzi do sprzeczności, ponieważ nie jest już więcej skutkiem, gdyż aby coś nim było, musi mieć przyczynę. Skoro nic nie może powstać samo z siebie ani też jako skutek z czegoś innego, to tym samym nie jest możliwe, aby powstawało z połączenia obydwu warunków. Na koniec, jak twierdzi, nie jest możliwe, aby cokolwiek powstawało bez określonej przyczyny. Doświadczana rzeczywistość charakteryzuje się bowiem uporządkowaniem następstw. Nie żyjemy w świecie, w którym, by użyć przykładu z sutr, „królikowi nagle wyrastają rogi”. W ten sposób odrzuca się wszystkie cztery

\footnotetext{
${ }^{8}$ Po śmierci Nagardżuny nastąpił rozłam w ufundowanej przez niego szkole filozoficznej, którego źródłem było dopuszczenie $\mathrm{w}$ rozważaniach innych, niż ustalona przez niego, metod. Różne stanowiska w tej kwestii doprowadziły do powstania dwóch nurtów w filozofii madhjamaka: (a) prāsañgika, której głównymi postaciami byli Buddhapālita (ok. 470 - 540 n.e.) oraz Candrakīrti (ok. VII w. n.e.); oraz (b) svātantrika, której czołowym przedstawicielem był Bhāvaviveka (ok. VI w. n.e.). Ci pierwsi kładli nacisk na metodę analityczną rozwijaną przez Nagardżunę, odrzucali możliwość formułowania pozytywnych twierdzeń bez popadnięcia w sprzeczność. Drudzy natomiast, kładąc akcent na praktyki medytacyjne, przedstawiali odmienną tendencję. Dopuszczali pozytywne twierdzenia na temat ostatecznej rzeczywistości i twierdzili, że Nagardżuna nie odrzucał wszelkich poglądów, lecz postępował antytetycznie - przyjmował stanowisko przeciwne do odrzuconego. Należy jednak zaznaczyć, że w obu podejściach pustka (śūnya) jest konceptem. Powstała na poziomie prawdy potocznej i przynależy do rzeczywistości konwencjonalnej. W ostatecznym rozrachunku i ona musi zostać odrzucona. Myśl ta wyrażona jest również w tekście Sutry Serca Doskonałej Mądrości (prajñā-paramita-hridaya-sūtra) uważanej za jedną $\mathrm{z}$ najważniejszych sutr mahajany, w której czytamy: „Forma jest Pustka, ale Pustka jest Forma. Pustka nie jest inna niż Formy, a Formy nie sa inne niż Pustka". Koncepcja Pustki i rzeczywistości ostatecznej okazuje się być tylko dydaktycznym wybiegiem i musi zostać porzucona, jak tylko osiągnie się oświecenie. W Lokātītastava Nagardżuna pisze: „Zbawiennym celem nauki o Pustce jest porzucenie wszelkich koncepcji. Jednak jeśli ktoś uwierzy w Pustke [jej obiektywne istnienie], jest zgubiony" (LS 23).
} 
możliwości. W analogiczny sposób Nagadżuna stara się pokazać, że z wszelkich pozytywnych twierdzeń na temat świata da się wyprowadzić sprzeczność, ponieważ u samej ich podstawy leży błędne założenie, że coś takiego jak świat istnieje $\mathrm{w}$ sposób niezależny, trwały i posiada istotę. Odrzucenie błędnych poglądów jest równoważne $\mathrm{z}$ porzuceniem konceptualnego postrzegania świata - głównej ich przyczyny. Logika jest tu zatem ważnym narzędziem umożliwiającym rozpoznanie problemów wywoływanych bezpodstawnie przyjmowanymi założeniami ontologicznymi.

Metoda ta wzbudzała kontrowersje już wśród myślicieli współczesnych buddyście. Twierdzili oni, że iluzoryczność świata konceptualnego jest unaoczniana przez Nagardżunę przy pomocy operującej na konceptach logiki. Pozornie więc natrafia on na tzw. paradoks nihilisty „skoro wszystkie twierdzenia są fałszywe, to twierdzenie, że wszystkie twierdzenia są fałszywe, też jest fałszywe". Należy pamiętać, iż buddyzm operuje dwoma poziomami rzeczywistości i dwoma odpowiadającymi im prawdami - konwencjonalną i ostateczną. Logika może pomóc zrozumieć błędność postrzegania świata jako składającego się $\mathrm{z}$ posiadających istotę bytów, sama również przynależy do prawdy konwencjonalnej i na poziomie ostatecznym też musi zostać porzucona. Funkcjonuje ona niczym narzędzie, które trzeba zostawić, gdy spełniło już swoje zadanie. Poza tym Nagardżuna był doskonale świadom tego faktu i swoje dzieło Vigrahavyāvartani, w którym stara się odeprzeć potencjalne zarzuty przeciwników swojej koncepcji, rozpoczyna od rozpatrzenia problemu podobnej natury9. Zarzut jaki sam sobie postawil jest następujący:

Jeśli wszelkie obiekty są pozbawione samobytu (svabhāva), to to, co mówisz również go nie posiada, a zatem nie jest możliwe, aby zaprzeczało istnieniu samobytu w innych obiektach. (VV I.I.)

Brak samobytu w wypowiedzi jest tutaj uważany za świadectwo jej niedorzeczności i przyczynę fałszywości stanu rzeczy przez nią stwierdzonego. Nagardżuna $\mathrm{w}$ odpowiedzi twierdzi, że pustka (śūnya) wcale nie oznacza, że dana rzecz nie jest w stanie pełnić określonej funkcji. Cały zarzut zatem polega na niezrozumieniu buddyjskiego postrzegania „pustki” (VV II.XXII).

\footnotetext{
${ }^{9}$ Bardziej szczegółową analizę omawianego fragmentu można znaleźć w: Chmielewski, 1981: 5157.
} 


\section{Soteriologia}

Jak wskazywaliśmy, wyzwolenie (i nirwana) jest $\mathrm{w}$ buddyzmie równoznaczne $\mathrm{z}$ uzyskaniem właściwego poglądu na naturę rzeczy. W przypadku Nagardżuny i jego filozofii ma się tu na myśli brak ich istoty, pustość. Podstawową rolę $\mathrm{w}$ ich uświadomieniu odgrywa logika, przy pomocy której poznaje się iluzoryczność reifikowanej rzeczywistości i uzyskuje podstawę do urzeczywistnienia jej prawdziwej natury. W buddyzmie wyróżnia się trzy poziomy zrozumienia: (a) „mądrość ze słuchania”, (b) „mądrość wynikającą z rozważania” oraz (c) „mądrość wynikającą z medytacji”. Pierwszy typ w zasadzie ogranicza się do samego tylko zrozumienia znaczeń użytych $\mathrm{w}$ naukach wyrażeń. Mądrość powstająca $\mathrm{z}$ rozważań to głębsze zrozumienie wynikające $\mathrm{z}$ analizy usłyszanych słów. Istotą trzeciego poziom mądrości jest medytacyjne urzeczywistnienie prawd zrozumianych intelektualnie, ich bezpośrednie doświadczenie odbywające się poza słowami. Logika umożliwia zdobycie mądrości z drugiego poziomu. Dzięki subtelnym rozważaniom sięgającym samych podstaw ontologicznych badanych obiektów okazuje się, że nie są one takimi, jakimi wydają się być. Jest to ważna funkcja dydaktyczna pokazująca, w jaki sposób nasze konceptualne schematy wypaczają ostateczną naturę rzeczywistości. Zrozumienie pustości (śūnyata) dokonuje się właśnie przez odrzucenie czterech możliwych sposobów przejawiania się zjawisk.

Wydaje się, że niewiele jest w historii logiki momentów, w których dziedzina ta doczekałaby się aż takiej nobilitacji - przyznającej jej ważną funkcję soteriologiczną. To właśnie logika umożliwia uświadomienie sobie własnego błędu poznawczego na poziomie analitycznym. Ponieważ logika jest częścią świata iluzorycznego, to jest konceptualna i opiera się na pozbawionych samobytu pojęciach. Nie jest zatem wcale tak, że rzeczywistość konwencjonalna jest czymś z gruntu rzeczy złym. Przeciwnie, stanowi ona ważny etap na drodze do wyzwolenia, właśnie w niej mającego swój początek i bez której nie jest ono możliwe:

Bez oparcia w prawdzie konwencjonalnej,

Nie sposób nauczać o wadze prawdy ostatecznej.

Bez zrozumienia wagi prawdy ostatecznej,

Nie osiągnie się wyzwolenia. (MMK XXIV 10)

W ostateczności trzeba również odrzucić logikę oraz będącą jej udziałem racjonalną analizę. Ostateczny wgląd w rzeczywistość absolutną jest już domeną praktyk medytacyjnych, których doświadczenia nie spełniają kryteriów racjonalności wiedzy - warunku intersubiektywnej komunikowalności. Rzeczywistość ostateczna jest wolna od wszelkich koncepcji, zatem na końcu tej drogi należy również porzucić pustkę oraz nirwanę. Sansara, nirwana i pustka to pojęcia takie same jak wszystkie inne i muszą zostać odrzucone. Prawda ostateczna jest pozapojęciowa i 
żadne rozróżnienia jej nie dotyczą. Z drugiej strony rzeczywistość ostateczna nie jest niczym innym jak rzeczywistością konwencjonalną postrzeganą w odpowiedni, zgodny z jej prawdziwym charakterem sposób. Zrównanie tej podstawowej dla filozofii Nagardżuny dystynkcji może zaskakiwać. Wydaje się jednak, że filozofia Wschodu straciłaby sporo ze swojego uroku, gdyby nie pozostawiała nas, ludzi uwikłanych $\mathrm{w}$ światopogląd zachodni, lekko zakłopotanych. Dlatego warto zakończyć tym jakże ważnym i „kontrowersyjnym” pouczeniem Nagardżuny:

Nic nie różni samsary od nirwany. Nic nie różni nirwany od samsary. Kres nirwany jest również kresem samsary. Nie ma między nimi nawet najmniejszej różnicy (MMK XXV.19-20).

Używane skróty:

AS - Nagardżuna. Acintayastava. w: Lindtner. 1997.

BV - Nagardżuna. Bodhicittavivarana. w: Lindtner. 1997.

LS - Nagardżuna. Lokātittastava. w: Lindtner. 1997.

MMK - Nagardżuna. Mūlamadhyamakakārikā.

VV - Nagardżuna. Vigrahavyāvartani. 


\section{Michat Lipnicki: Język, logika i soteriologia}

\section{Bibliografia}

Bocheński, I. M. 1957. Ancient Formal Logic. Amsterdam: North-Holland Publishing Company.

Chmielewski, J. 1981. Zasada redukcji do absurdu na tle porównawczym. w: Studia Semiotyczne, vol. 11, pp. 21-106.

Ganeri, J. 2004, Indian Logic. w: Dov M. Gabbay, John Woods (Eds). Handbook of the History of Logic. Volume 1: Greek, Indian and Arabic Logic. Amsterdam: Elsevier. pp. 309-395.

Gethin, R. 2010. Podstawy buddyzmu. Kraków. Wydawnictwo Uniwersytetu Jagiellońskiego.

Gunaratne, R. D. 1980. The Logical Form of Catușkoți: A New Solution. w: Philosophy East \& West, vol. 30, pp. 211-239.

Jayatilleke, K. N. 1963. Early Buddhist Theory of Knowledge. London: George Allen \& Unwin LTD.

Jayatilleke, K. N. 1967. The Logic of Four Alternatives. w: Philosophy East \& West, vol. 17, pp. 69-83.

Lindtner, Ch. 1997. Master of Wisdom. Writings of the Buddhist Master Nāgārjuna. Ratna Ling: Dharma Publishing.

Malinowski, G. 2010. Logika ogólna. Warszawa: Wydawnictwo Naukowe PWN.

Marciszewski, W. (ed.) 1970. Mała encyklopedia logiki. Wrocław: Zakład Narodowy im. Ossolińskich.

Matilal, B.K. 1971. Epistemology, Logic and Grammar in Indian Philosophical Analysis. The Hague: Mouton.

Mejor, M. 2001. Buddyzm. Zarys historii buddyzmu $w$ Indiach. Warszawa: Prószyński i S-ka.

Nagardżuna. 1995. Mūlamadhyamakakārikā. w: Garfield, J. L. The Fudamental Wisdom of The Middle Way. Oxford, New York: Oxford University Press.

Nagardżuna. 2005. Vigrahavyāvartani. w: K. N. Bhattacharya. The Dialectical Method of Nāgārjuna. Vigrahavyāvartani. Delhi: Motilal Banarsidass Publishers.

Quine, W. O. 2002. Filozofia logiki. Warszawa: Fundacja Aletheia.

Radhakrishnan, S. 1958. Filozofia indyjska, vol. 1. Warszawa: Instytut wydawniczy PAX.

Robinson. R. H. 1957. Some Logical Aspects of Nāgārjuna's System. w: Philosophy East \& West, vol, 6, pp. 291-308.

Suchoń, W. 2001. Wykłady o dziejach logiki dawniejszej. Kraków: Wydawnictwo Uniwersytetu Jagiellońskiego.

Suszko, R. 1998. Wstęp do zagadnień logiki. w: R. Suszko, Wybór pism. Warszawa: Biblioteka Myśli Semiotycznej.

Williams, P. 2001. Buddyzm Mahajana. Kraków: Wydawnictwo A. 